Check for updates

1 Department of Surgery, University of California, Los Angeles, CA, USA

2 Department of Surgery, Soroti Regional Referral Hospital, Uganda

3 Department of Infectious Diseases, Hospital Universitario San Ignacio, Bogotá, Colombia

4 Pontificia Universidad Javeriana, Hospital Universitario San Ignacio, Bogotá, Colombia

5 Department of Surgery, University of Buea, South-West Region, Cameroon

Correspondence to: K Garber KGarber@mednet.ucla.edu Cite this as: BMJ2020;370:m2727 http://dx.doi.org/10.1136/bmj.m2727 Published: 15 July 2020

\section{Structural inequities in the global supply of personal protective equipment}

\author{
Low and middle income countries are priced out and facing severe shortages
}

\author{
Kent Garber, ${ }^{1}$ Mary Margaret Ajiko, ${ }^{2}$ Sandra M Gualtero-Trujillo, ${ }^{3,4}$ Samuel Martinez-Vernaza, ${ }^{3}$ \\ Alain Chichom-Mefire ${ }^{5}$
}

From March until late May Uganda was under strict lockdown to reduce the spread of covid-19. A curfew went into effect every night; public transportation was suspended. Although some restrictions have since eased, and confirmed cases only recently topped 1000, concerns about covid-19 remain high, particularly among healthcare workers. The main supplier of personal protective equipment (PPE) to the regional referral hospital in Soroti, located about $320 \mathrm{~km}$ northeast of the capital city Kampala, was out of stock for most of this spring, with no word on when new shipments would arrive.

Many low and middle income countries are facing similar concerns, particularly as covid-19 outbreaks deepen around the world. Amid the ongoing pandemic, global PPE supply chains have been upended: demand is soaring, prices are rising, and an international bidding war has ensued, with many low and middle income countries being outbid and priced out. ${ }^{1}$ In Cameroon, $\mathrm{N}-95$ respirator masks are almost non-existent and basic surgical masks are scarce. In Uganda, suppliers have run out of PPE entirely. Middle income countries are also facing crunches: a survey of Colombian health workers found nearly $90 \%$ of respondents worked in facilities lacking N95 masks or face shields. ${ }^{2}$

In recent months, high income countries have been scrambling not only to secure PPE shipments but also to deploy technologies to reuse and decontaminate PPE. ${ }^{3-5}$ But what are the options for low and middle income countries? Many PPE decontamination technologies are resource intensive and costly. An ultraviolet radiation tower costs $\$ 25000-\$ 40000$ (£20 000-€32 000; €22 000-€35 000), and a hydrogen peroxide vaporisation unit $\$ 40000-\$ 130000$ (personal communication). Some countries, or select hospitals within countries, might find such investments cost effective; at least one university affiliated hospital in Bogotá, Colombia, has adopted hydrogen peroxide protocols. Yet the price tag may limit more widespread adoption. Potentially cheaper methods, including moist heat and microwave generated steam, are being investigated, but these have limitations. ${ }^{6}$

Shortages of PPE are nothing new for many low and middle income countries; systemic inequities in the supply chain were compromising healthcare delivery and health worker safety long before covid-19 appeared. During the 2014-15 Ebola outbreak in west Africa, healthcare workers were 20-30 times more likely to be infected than the general population, partly because of pervasive PPE shortages. ${ }^{7}$ Despite the international publicity around Ebola, those gaps have persisted. A recent pre-pandemic study from seven low income countries found eye protection available in only $37 \%$ of hospitals and $9 \%$ of health centres or clinics. In four countries, fewer than a third of primary level health facilities had face masks. ${ }^{8}$

Robust supply chains have three core elements: they should be continuous, sustainable, and deliver high quality products. ${ }^{9}$ Yet in many countries, external and internal factors have hampered supply chain development. Historically, infrastructure for the procurement, storage, and distribution of medical supplies has been underfinanced, and international vertical programmes for specific diseases (such as malaria and HIV) have fuelled parallel and fragmented supply chains, contributing to shortages and waste. ${ }^{10}$ Supply chains in many low and middle income countries rely on "push systems," whereby centralised agencies distribute medicines and supplies top-down, rather than more responsive "pull systems," in which facilities determine need based on actual consumption. ${ }^{11}$ Meanwhile, production too often remains concentrated among a few international companies, ${ }^{9}$ leaving countries vulnerable to price swings and disruptions.

\section{Innovative responses}

In the current pandemic, many low and middle income countries are innovating policy responses to these deeply rooted challenges. The African Union has organised a continent focused taskforce and launched a medical supply platform to streamline procurement and reduce reliance on donations. ${ }^{12} 13$ National regulatory agencies, such as Colombia's, have adopted policies to accelerate imports and encourage domestic production. ${ }^{14}$ The Bogotá Chamber of Commerce has built a digital platform to connect PPE suppliers and local end users. Businesses are responding, too. In Uganda, one company is making face shields from recycled plastics. Countries are taking other steps to protect health workers, including establishing agencies to evaluate the quality of locally made PPE.

In addition, multilateral institutions and global non-profit organisations are ramping up funding for covid-19 programmes. These programmes are critical to a timely response but should be designed to reduce not reinforce existing problems in the supply chain. A more strategic response to covid-19 could lay the groundwork for longer term structural reforms, including investing in information technology, infrastructure, and training in supply chain 
management and expanding domestic manufacturing.

At the same time, the international community could do more to help, rather than hamper, local responses. The United Nations recently formed a supply chain taskforce on global PPE procurement and distribution. This taskforce could be empowered with real responsibilities, including investigating price gouging and increasing market transparency by publicising lists of suppliers alongside their prices and practices. Western governments could relax policies that have reduced exports and placed restrictions on the use of foreign aid to buy PPE. And buyers and advocates could put pressure on manufacturers to adopt fair pricing policies, similar to those adopted for vaccinations and essential medicines.

These measures won't solve systemic inequities in supply chains overnight, but they would go a long way towards promoting a more equitable global response to covid-19-one that could save lives, protect health workers, and support more resilient health systems.

Competing interests: We have read and understood BMJ policy on declaration of interests and declare the following interests: KG has done consulting work for the World Bank focusing on healthcare delivery in fragile and conflict affected countries.

Provenance and peer review: Not commissioned; externally peer reviewed.

We thank Catherine Juillard, Kevin J Blair, and Dennis Zheng from the University of California, LoS Angeles, for their contributions.

1 Bradley J. In scramble for coronavirus supplies, rich countries push poor aside. New York Times 2020 Apr 9. https://www.nytimes.com/2020/04/09/world/coronavirus-equipment-rich-poor.html

2 Corcho C, Arrieta M, Patiño S, Barbosa S. Encuesta de bioseguridad del personal de la salud y ruta de atención de la pandemia SARS-COV2-COVID-19. Epicrisis 22 May 2020 . https://epicrisis.org/2020/04/12/encuesta-de-bioseguridad-del-personal-de-la-salud-y-ruta-de-atencion-dela-pandemia-sars-cov2-covid-19/

3 Centers for Disease Control and Prevention. Recommended guidance for extended use and limited reuse of N95 filtering facepiece respirators in healthcare settings. 2020. https://www.cdc.gov/niosh/topics/hcwcontrols/recommendedguidanceextuse.html

4 Lore MB, Heimbuch BK, Brown TL, Wander JD, Hinrichs SH. Effectiveness of three decontamination treatments against influenza virus applied to filtering facepiece respirators. Ann Occup Hyg 2012;56:92-101.pmid: 21859950

5 Fisher E, Rengasamy S, Viscusi D, Vo E, Shaffer R. Development of a test system to apply virus-containing particles to filtering facepiece respirators for the evaluation of decontamination procedures. Appl Environ Microbiol2009;75:1500-7. doi: 10.1128/AEM.01653-08 pmid: 19139225

6 N95Decon. Technical report for heat and humidity N95 reuse. https://www.n95decon.org/publications.

7 WHO. Health worker Ebola infections in Guinea, Liberia and Sierra Leone. Preliminary report. 2015. https://www.who.int/csr/resources/publications/ebola/health-worker-infections/en/

8 Gage A, Bauhoff S. Health systems in low-income countries will struggle to protect health workers from covid-19. Center for Global Development, 2020. https:/www.cgdev.org/blog/health-systemslow-income-countries-will-struggle-protect-health-workers-covid-19

9 Beran D, Mirza Z, Dong J. Access to insulin: applying the concept of security of supply to medicines. Bull World Health Organ 2019;97:358-64. doi: 10.2471/BLT.18.217612 pmid: 31551632

10 Barr A, Garrett L, Marten R, Kadandale S. Health sector fragmentation: three examples from Sierra Leone. Global Health 2019;15:8. doi: 10.1186/s12992-018-0447-5. pmid: 30670026

11 Vledder M, Friedman J, Sjöblom M, Brown T, Yadav P. Improving supply chain for essential drugs in low-income countries: results from a large scale randomized experiment in Zambia. Health Syst Reform 2019;5:158-77. doi: 10.1080/23288604.2019.1596050 pmid: 31194645

12 Nkengasong J. Let Africa into the market for COVID-19 diagnostics. Nature 2020;580:565. doi: 10.1038/d41586-020-01265-0 pmid: 32346145

13 Government of South Africa. South Africa: President Cyril Ramaphosa provides public update on continental strategy to fight coronavirus covid-19. 18 Jun 2020. https://allafrica.com/stories/202006180634.html

14 Invima. Productos para la prevención, diagnóstico y tratamiento del COVID-19 con flexibilidad de requisitos o que no requieren aprobación del Invima para su producción e importación en el país Colombia: Invima; 2020. https://www.invima.gov.co/productos-para-la-prevencion-diagnostico-y-tratamiento-del-covid-19-con-flexibilidad-de-requisitos-o-que-no-requieren-aprobaciondel-invima-para-su-produccion-e-importacion-en-el-pais. 